\title{
A SUSTAINABLE ANALYSIS OF A DETACHED HOUSE HEATING SYSTEM THROUGHOUT ITS LIFE CYCLE. A CASE STUDY
}

\author{
Violeta SASNAUSKAITE் ${ }^{\mathbf{1}}$, Lina UŽŠILAITYTĖ ${ }^{2} \bowtie$ and Artur ROGOŽA ${ }^{\mathbf{3}}$ \\ 1 Department of Heating and Ventilation, Vilnius Gediminas Technical University, Sauletekio \\ al. 11, LT-10223 Vilnius, Lithuania \\ E-mail: violeta.svk@gmail.com \\ 2 Department of Heating and Ventilation, Vilnius Gediminas Technical University, Sauletekio \\ al. 11, LT-10223 Vilnius, Lithuania \\ E-mail:l.uzsilaityte@gmail.com \\ 3 Department of Heating and Ventilation, Vilnius Gediminas Technical University, Sauletekio \\ al. 11, LT-10223 Vilnius, Lithuania \\ E-mail: artur.rogoza@ap.vgtu.lt
}

Received 3 November 2006; accepted 27 April 2007

\begin{abstract}
Approximately $40 \%$ of final energy is consumed in buildings both in Lithuania and the European Union. In cold climate countries major part of the consumed energy is heat. Therefore, in order to build energy efficient buildings it is very important at the design stage to make a right decision regarding the choice of the heating system. The aim of the study is to compare three different heating systems from the point of view of a sustainable development concept. This paper summarizes results of the life cycle analysis, which has been made on the heating systems of an existing residential building. The purpose of this study is to define the primary energy consumption, $\mathrm{CO}_{2}$ emissions and investments necessary for the three different heating systems during their life span and to evaluate them applying a multicriteria approach. The systems under consideration are the heating systems comprising a standard cast-iron gas boiler and steel radiators or a condensing gas boiler combined with floor heating or a condensing gas boiler combined with steel radiators. A life cycle assessment has been made for the life span of 80 years. As a final decision making criteria the $3 \mathrm{E}$ criteria is proposed.
\end{abstract}

KEYWORDS: LCA; Heating system; Energy consumption; $\mathrm{CO}_{2}$ emissions; $3 \mathrm{E}$ criteria

\section{INTRODUCTION}

Buildings are a valuable state property and major energy end-users. Approximately $40 \%$ of final energy is consumed in buildings both in Lithuania and in the whole European Union (Department of Statistics under the Government of the Republic of Lithuania, 2006; Eurostat, 2007). Much attention is paid to the improved energy efficiency in building sector during the last years, because the sector harbours a considerable potential of primary energy saving and reduction of emissions, having a negative impact on the environment.

In order to build energy efficient buildings, correct decisions have to be made already at the design stage. Heating system is among the systems, which are responsible for the consumption of the major part of energy in cold climate countries. It means that the design of

International Journal of Strategic Property Management

ISSN 1648-715X print / ISSN 1648-9179 online (C) 2007 Vilnius Gediminas Technical University http://www.ijspm.vgtu.lt 
this system can influence the overall energy performance of the building.

To evaluate overall energy performance of the building, it is not enough to use single criteria. Systematic decision-making methods are needed. The methods, such as the life cycle assessment and a multi-criteria decision-making method could be mentioned. These methods allow making the evaluation of the systems with regard to the concept of the sustainable development. It means that application of the methods could assist in solving energy, environment and economical issues.

More and more attention is paid to an environmental management tool - the life cycle assessment. This tool allows evaluating product/system impact on environment and also on primary energy consumption during the whole product/system life cycle. This tool is used in research and in practise. For example, requirements to evaluate the impact on environment of the energy-using products during its whole life cycle are set in directive 2005/32/EC of the European Parliament and of the Council of 6 July 2005 establishing a framework for the setting of eco-design requirements for energyusing products and amending Council Directive 92/42/EEC and Directives 96/57/EC and 2000/55/EC of the European Parliament and of the Council. Directive 2006/32/EC of the European Parliament and of the Council of 5 April 2006 on energy end-use efficiency and energy services and repealing Council Directive 93/76/EEC recommends to use minimised life cycle cost analysis in particular cases. Life cycle assessment allows solving problems without creating them in other places.

A number of studies about the building and its energy systems' life cycle have been conducted. Some of them are dedicated to the building construction's life cycle (Asif, Muneer and Kelley, 2007; Blanchard and Reppe, 1998; European Commission, 1997). Some of them deal with the building construction and energy systems' life cycle (Martinaitis, 2001; Scheuer,
Keoleian and Reppe, 2003). Some of them analyse energy systems (Prek, 2004).

However, most of the studies analyse building construction materials. Studies dealing with the analysis of energy systems usually take into account only the main elements (heating devices and pipes) and the basic materials (Martinaitis, 2001; Prek, 2004).

Total energy use in a life cycle perspective includes energy needed for both operational and embodied energy. Numerous studies throughout the international community have shown that operational energy accounts for the main amount of total energy use in dwellings during an assumed life span of 50 years what makes approximately 85-95\% of total energy use. Energy needed for operations can be reduced considerably by improving the insulation of the building envelope, technical solutions, etc. However, studies have also shown that the total energy needed in a low-energy building may be even higher than in a building with a higher amount of energy needed for operation, because large amounts of energy are needed for production and maintenance of the technical equipment. Therefore, as the energy needed for operation decreases, more attention has to be paid to the energy use for the material production (Thormark, 2006).

Nevertheless, taking into account the sustainable development concept, not only energy and environmental aspects are important. The economy is the last but not least aspect. The system's impact on environment and energy consumption can be reduced to the minimum, but if it is not economically affordable, nobody will use such system.

Seeking to evaluate energy systems according to the concept of sustainability, the socalled 3E (Energy, Economy, Environment) criteria have been proposed. The concept evaluates and optimises technical systems from the point of view of energy, economy and environment (Rogoža, Čiuprinskas and Šiupšinskas, 2006). 
The goal of the study was to compare three different heating systems during their life cycle with regard to energy, environment and economy. The systems analysed: a radiator system with cast-iron boiler; a radiator system with a condensing boiler and a floor - heating system with a condensing boiler. All the elements of the heating system (boiler-room equipment, heating devices, pipes, insulation, control fittings, etc.) have been taken into account. Elements and materials that make the major impact on primary energy consumption and environment have been evaluated and the investments necessary for the systems have been calculated. The systems have been compared applying the $3 \mathrm{E}$ method.

\section{METHODS}

In this study the life cycle assessment (LCA) method is used for the evaluation of heating system impact on the environment.

A life cycle analysis and assessment (also known as life cycle analysis, life cycle inventory, Ecobalance, cradle to grave analysis and material flow analysis) is the assessment of the environmental impact of a given product or service throughout its lifespan (Moberg, 2006). In other words - LCA is a process of evaluating the effects that a product has on the environment over the entire period of its life thereby increasing resource-use efficiency and decreasing liabilities (Sustainable AgriFood Production and Consumption Forum of the United Nations Environment Program, 2000).

This method can be used to study the environmental impact of a product, service or the function the product is designed to perform (Moberg, 2006; Sustainable Agri-Food Production and Consumption Forum of the United Nations Environment Program, 2000). All elements of the production chains are analysed, from raw materials extraction through processing, transport, energy conversion, and waste management. Therefore, both direct and indirect burdens are accounted for emissions to air, water and soil as well as resource use (PSI, 2004). LCA lets to choose the least burdening product or service (Moberg, 2006; Sustainable Agri-Food Production and Consumption Forum of the United Nations Environment Program, 2000).

For understanding of the basic elements and requirements for LCA studies, ISO standards were created: ISO 14040, 14041, 14042 and 14043. These standards give better understanding of the idea of LCA and also describe how this method should be used and how data should be interpreted. According to these standards, LCA consists of four iterative phases (Fava, 2006; U.S. Environmental protection agency, 2006) (see Figure 1):

1) Goal and Scope Definition (ISO 14040): Definition of the goals, product system, and boundaries of the study;

2) Inventory Analysis (ISO 14041): raw materials, energy and emissions related to the product system are quantified and related to the product function. This stage is often called input/ output analysis;

3) Impact Assessment (ISO 14042): the outcome of the inventory is analysed with respect to their environmental relevance and is aggregated within a smaller number of relevant environmental issues;

4) Interpretation (ISO 14043): the results are compared with the goal of the study.

It should be mentioned, that the most complicated part of the analysis is inventory analysis, because obtaining process data necessary to conduct inventories continues to be difficult due to logistical as well as psychological barriers (such as a fear by industry of sharing data and thereby revealing confidential corporate) and it is often difficult to get data on national level (Moberg, 2006). Finding data is very hard and usually very time-consuming. Published 


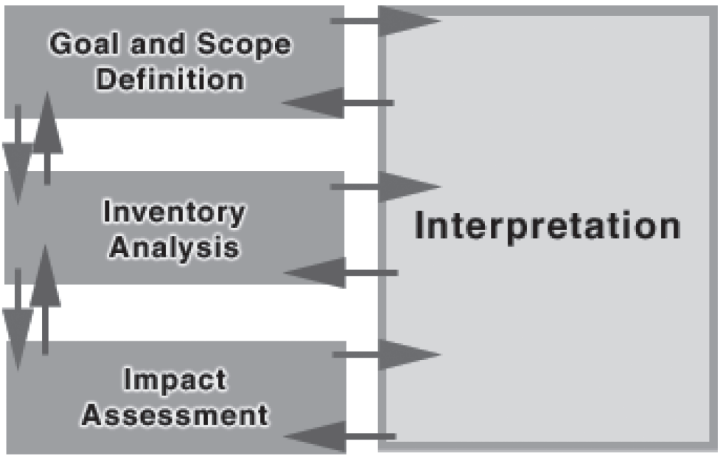

Figure 1. Main steps of LCA

Source: U.S. Environmental protection agency (2006)

data on material loads exists, but is often inconsistent and/or not directly applicable (Bras and Roman, 2006).

First of all, data collection is driven by the goal of the study, therefore, it is necessary to make assumptions on which accuracy of the results will depend.

The other method used in the study, was the $3 \mathrm{E}$ method. A concept of this method is based on LCA. According to this method, an optimal system is a system with minimal energy consumption, minimal emissions and minimal expenditures during the whole life cycle of that system (minimal value of the $3 \mathrm{E}$ criteria). It can be set using the equation:

$$
3 E=e_{n} \cdot s_{e}+k_{n} \cdot s_{k}+c_{n} \cdot s_{c}
$$

where: $e_{n}$ - non-dimensional value of the energy consumption (non-dimensional value express the same results of the variants under consideration but in percents, e. g. zero value is set to the minimal result, one - to the maximum, other values are between zero and one); $k_{n}$ - non-dimensional value of the expenditures; $c_{n}$ - non-dimensional value of the emissions produced; $s_{e}, s_{k}, s_{c}$ - weight coefficients.

Equations for the estimation of non-dimensional values are:

$$
e_{n}=1-\frac{E_{\max }-E_{n}}{E_{\max }-E_{\min }}
$$

$$
\begin{aligned}
& k_{n}=1-\frac{K_{\max }-K_{n}}{K_{\max }-K_{\min }} ; \\
& c_{n}=1-\frac{C_{\max }-C_{n}}{C_{\max }-C_{\min }} .
\end{aligned}
$$

The values of weight coefficients $s_{e}, s_{k}, s_{c}$ can be chosen according to the goals of the evaluator (Rogoža, Čiuprinskas and Šiupšinskas, 2006).

\section{CASE STUDY}

\subsection{Object description}

Heating systems are designed to operate in an existing detached one-storey single-family building, located in Vilnius, Lithuania. Its floor area is $256.7 \mathrm{~m}^{2}$. Heat carrier is furnished from the manifold by plastic pipes to steel radiators or floor heating pipes (depending on the system type). Heating pipelines from boiler-room to the manifolds are steel, insulated with mineral wool. Required heating capacity of the building is $24 \mathrm{~kW}$. Heat is generated in a castiron gas boiler or condensing gas boiler installed in the local boiler room. Mechanical ventilation system with heat recovery is designed in the building, but it doesn't affect heat consumption, as the air heater is electrical.

One of the reasons, why the gas boiler has been chosen, is the current popularity of such boilers in Lithuania. According to some already made LCA analysis (Dones, Gantner and Hirschberg, 1999; Dones, Heck, and Hirschberg, 2003), the second reason to prefer gas is because it is the best fossil fuel from the ecological point of view.

\subsection{Goal and scope definition}

Goal of the study is to compare three different heating systems designed for the residential building during their life cycle with regard to energy, environment and economy. De- 
cision-making is based on the $3 \mathrm{E}$ criteria.

As a functional unit a square meter of the building is chosen.

Boundaries of the life cycle assessment cover raw material extraction and processing, design, production, packaging, transportation, distribution, use, reuse, recycling and final disposal.

In this study due to the lack of data, negligible importance and unknown behaviour of the user in advance of particular phases, design, packaging, reuse, recycling and final disposal phases are not taken into consideration.

Main materials production of the heating system elements, manufacturing of the heating system elements, transportation, reconstruction and operation phases are evaluated. A scheme of the analysis is shown in Figure 2.

The materials production phase includes raw material extraction, transportation to the processing place and materials production for the elements manufacturing.

Transportation phase includes transporta- tion of heating system elements from country manufacturer to Lithuania and distribution of these elements to the sale and building lot.

Life cycle of the heating system is assumed to be 80 years and is the same as the life time of the building. Two main reconstructions of the heating system will be performed during the lifetime. Also replacement of the obsolete elements (like automatic control valves, boiler, chimney and pump) between reconstructions will be performed. Replacement period of the obsolete heating system elements is assumed according to the lifetime of each element (European committee for standardisation, 2003; Ministry of the Environment of the Republic of Lithuania, 2001). It is assumed that building thermal conditions will not be improved and heating capacity will remain unchanged.

In this study the impact on the primary energy consumption, $\mathrm{CO}_{2}$ emissions, investments into the heating system are evaluated.

Number of assumptions was made during the evaluation of the system life cycle:

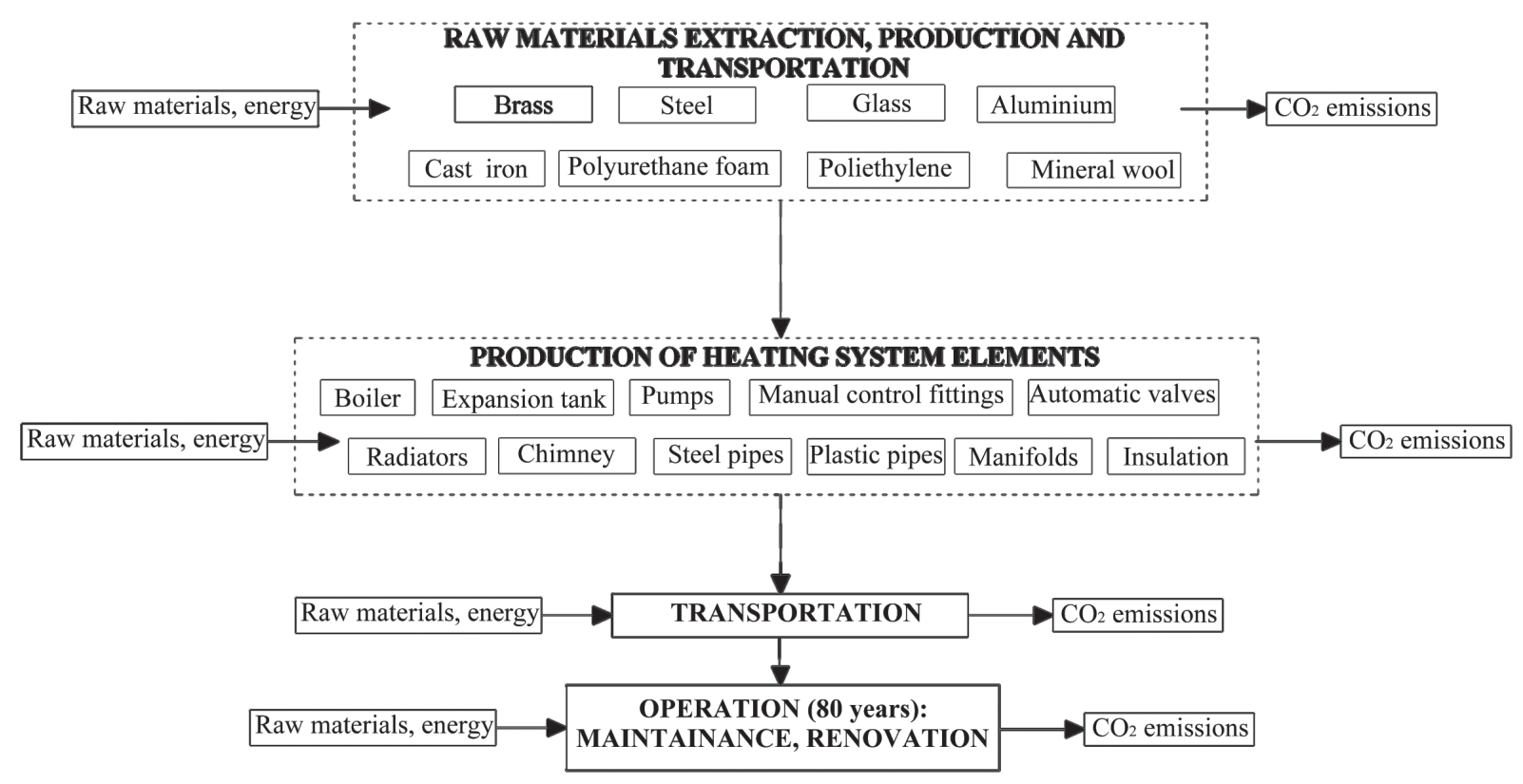

Figure 2. Process flow chart for heating system 
1. When exact composition of the elements was not known, minor parts were not taken into account. Even when compositions were known, they were not evaluated because of their small quantities.

2. Steel and stainless steel were analysed as steel.

3. Other assumptions are discussed in separate sections.

\subsection{Inventory analysis}

First of all materials balance has to be done.

It was defined, that radiator-heating system with cast-iron gas boiler contains steel, cast-iron, polyethylene, mineral wool, aluminium, brass, glass and polyurethane foam. Main material of this system is steel, which amounts up to $80 \%$ of the total mass balance. The second largest material is cast-iron, which amounts $8 \%$ of the total mass balance. The rest six materials amount only $12 \%$.

System with steel radiators and condensing boiler mainly contains steel $-88 \%$ of the whole mass.

Materials balance analysis showed that floor heating system combined with condensing boiler contains mainly steel $-76 \%$ and polyethylene $-16 \%$.

\section{Materials production}

Primary energy consumption and emissions from steel, polyethylene, mineral wool, brass, glass and cast-iron production are taken from SimaPro 7 software. These data are based on the European production data (Pre Consultants bv, 2006).

Primary energy consumption and emissions from aluminium production are taken from International aluminium institute data. Raw material extraction, transportation and production process are evaluated (International Aluminium Institute, 2003; International Aluminium Institute, 2000).

Primary energy consumption and emissions from polyurethane production are taken from the European Isocyanate Producers Association (ISOPA, 1998). Production of main polyurethane foam components (pentane, polyol and methyl diphenil acetate) and production of foam has been analysed. In this case packaging and first level transportation are already evaluated in the study. Data supplied are partly based on practical data, partly are calculated theoretically, but are suitable to use for the European conditions.

Primary energy consumption and $\mathrm{CO}_{2}$ emissions during materials production phase of different materials are presented in Table 1.

Table 1. Primary energy consumption and $\mathrm{CO}_{2}$ emissions during materials production phase

\begin{tabular}{lll}
\hline Material & Primary energy consumption, $\mathrm{MJ} / \mathrm{kg}$ & Emissions, $\mathrm{kgCO}_{2} / \mathrm{kg}$ \\
\hline Steel & 30.6 & 2.6 \\
Polyethylene & 75.7 & 0.94 \\
Mineral wool & 18.1 & 1.34 \\
Aluminium & 193.7 & 10.5 \\
Brass & 94.3 & 5.0 \\
Glass & 12.1 & 0.75 \\
Cast iron & 65.7 & 4.0 \\
Polyurethane foam & 104.7 & 3.7 \\
\hline
\end{tabular}

Source: International Aluminium Institute (2003); International Aluminium Institute (2000); ISOPA (1998); Pre Consultants bv, (2006). 


\section{Manufacture}

As inventory data about heating system elements manufacturing was not found, it was assumed that during this process $15 \%$ of primary energy in materials production phase is consumed and $15 \%$ emissions in materials production phase are emitted (Nyman and Simonson, 2005; Prek, 2004).

\section{Transportation}

Heating system elements are manufactured in different countries and are transported to Lithuania. Also they are transported to the sale place and to the building lot.

It is assumed that transportation distance of the elements from the manufacturer country to Lithuania is $1000 \mathrm{~km}$ and distribution distance is $100 \mathrm{~km}$ (to the sale place and build- ing lot). Except for insulation, because it is produced in Lithuania and only distribution distance is evaluated.

It is assumed that heating system elements are transported by $16 \mathrm{t}$ truck and distributed across the territory by van $(<3,5 \mathrm{t})$. Inventory data include road infrastructure building, manufacturing of the vehicle, maintenance and final disposal. Data are based on the studies done in Germany, Switzerland and USA (Pre Consultants bv, 2006).

Primary energy consumption and emissions during transportation and distribution of different vehicles are presented in Table 2.

\section{Reconstruction}

During operation of heating system several elements of the system have to be replaced.

Table 2. Primary energy consumption and emissions during transportation and distribution

\begin{tabular}{lll}
\hline & Truck & Van \\
\hline Primary energy consumption, $\mathrm{MJ} / \mathrm{kgkm}$ & 0.000752 & 0.0146 \\
Emissions to the atmosphere, $\mathrm{kgCO}_{2} / \mathrm{kgkm}$ & 0.000028859 & 0.000996 \\
\hline
\end{tabular}

Source: Pre Consultants bv, (2006).

Table 3. Life spans of the heating system elements

\begin{tabular}{lll}
\hline No & Elements of the heating system & Life time, years \\
\hline 1. & Radiator & 30 \\
2. & Manifold & 30 \\
3. & Steel pipe & 30 \\
4. & Plastic pipes & 30 \\
5. & Insulation & 30 \\
6. & Manual control fittings and measurement devices & 30 \\
7. & Thermostats & 15 \\
8. & Boiler & 20 \\
9. & Expansion tank & 15 \\
10. & Circulation pumps & 20 \\
11. & Automatic control valves & 15 \\
12. & Chimney & 20 \\
\hline
\end{tabular}

Source: European committee for standardisation (2003); Ministry of the Environment of the Republic of Lithuania (2001). 
The life spans of separate heating system elements are given in Table 3.

According to the lifetime of separate heating system elements, it is assumed that:

- Thermostats will be replaced in 15, 30, 45, 60 and 75 year of operation;

- Boiler, pumps and chimney will be replaced in 20, 40 and 60 year of operation;

- Other elements will be replaced during reconstruction of the system, which will take place in 30 and 60 year of operation.

Additional inputs and outputs were not evaluated during reconstruction.

\section{Operation}

In this phase the amount of primary energy for heat and electricity production and $\mathrm{CO}_{2}$ emissions from this production during 80 year of operation of the system are calculated.

Primary energy consumption for heat production is calculated according to the climatic data of Vilnius. Primary energy consumption for electricity production is evaluated assum- ing that the performance coefficient for electricity production is 3 (Schmidt, 2004).

$\mathrm{CO}_{2}$ emissions is calculated according to the data included in the National Allocation Plan of Lithuania for 2005-2007 (Ministry of Economy of the Republic of Lithuania, 2004).

The efficiency of the cast-iron gas boiler is assumed to be $92 \%$ during the evaluation of the operation stage of the radiator heating system.

Meantime the condensing gas boiler can reach maximal efficiency of $109 \%$, but just when it operates in low temperatures, its efficiency is just $6-10 \%$ higher than that of a standard gas boiler. Since the size of radiators in the system with the condensing gas boiler remained unchanged, it has to work at high temperatures to supply the required heat amount, and their efficiency is assumed to be $98 \%$.

Floor heating needs low temperature heat carrier, in this case maximum efficiency (109\%) of condensing boiler can be reached.

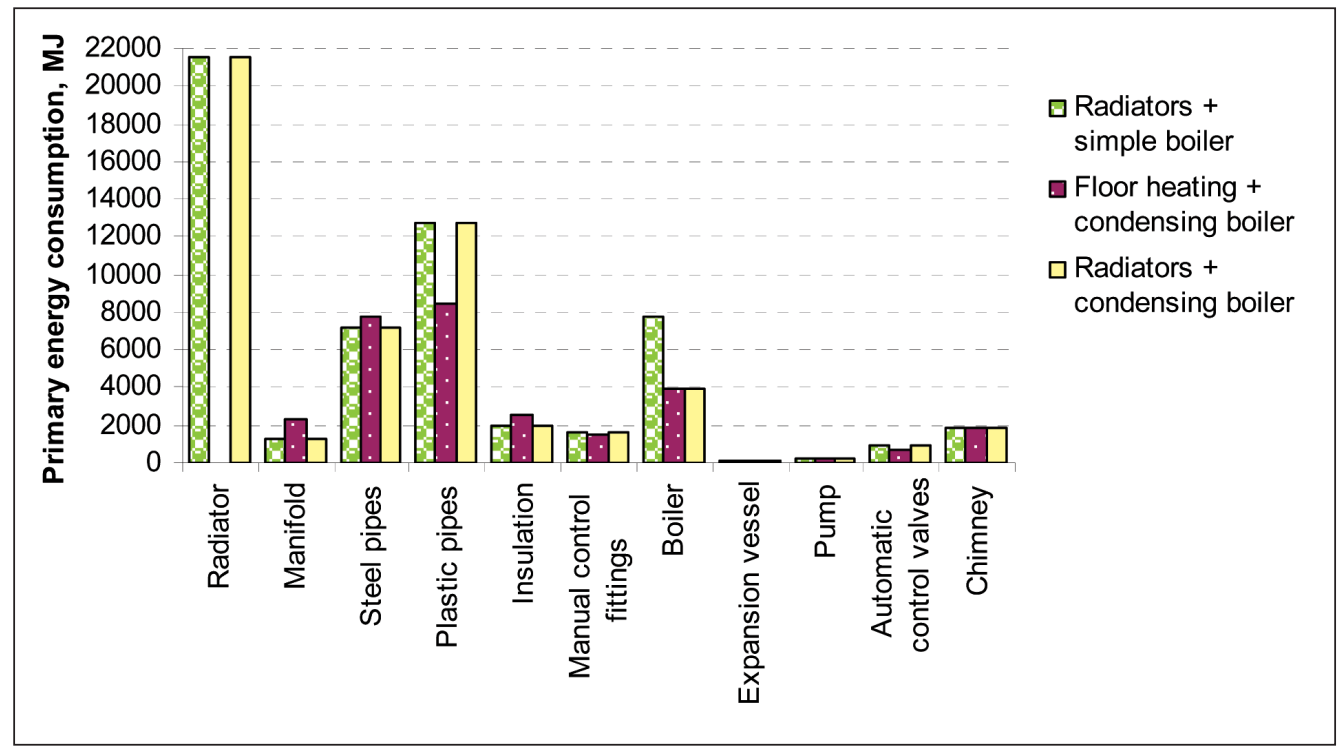

Figure 3. Comparison of primary energy consumption during materials production phase of the heating systems elements 


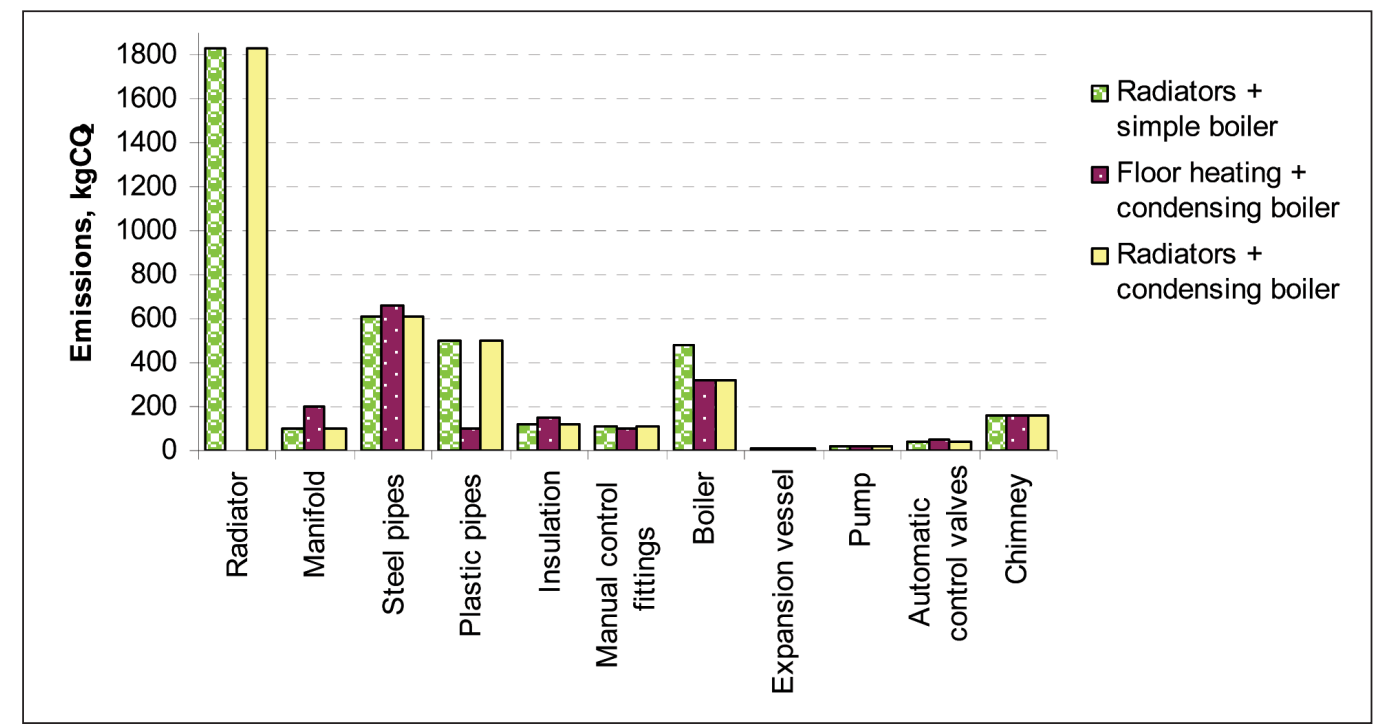

Figure 4. Comparison of $\mathrm{CO}_{2}$ emissions during materials production phase of the heating systems elements

\subsection{Impact assessment}

After a detailed review of the life cycle of the heating systems and collecting inventory data, an impact assessment was performed.

In Figure 3 and 4 primary energy consumption and $\mathrm{CO}_{2}$ emissions during materials production phase of each heating system element are presented accordingly.

As it can be seen from the figures above, during the production phase, radiators need the most energy and emit the biggest amount of $\mathrm{CO}_{2}$. In case of floor heating system, heating devices (plastic pipes) consume much less energy and emit less carbon dioxide.

The second largest contributors are steel and plastic pipes. Steel pipes, when compared with the plastic pipes, make bigger impact on environment but less impact on primary energy consumption.

Radiators and pipes have the biggest impact on both energy and environment in comparison to other elements of the system. The reason why these elements make the biggest impact is their weight. They constitute the big- gest share in the mass balance $-49-77 \%$ depending on the system.

Energy consumed and $\mathrm{CO}_{2}$ emitted mainly depends on the type of heating system devices. Systems with steel radiators contain mainly steel, therefore their impact during materials production phase is much higher.

Primary energy consumption and $\mathrm{CO}_{2}$ emissions in particular phases of the heating system life cycle are presented in Table 4 and 5.

As it can be seen from the Table 4 and 5, during the whole life cycle the smallest amount of energy is consumed by the system "floor heating + condensing boiler". This system is also the most environmentally friendly.

The most important phase during the life cycle of the heating systems is the operation phase where $99 \%$ of primary energy is consumed and $\mathrm{CO}_{2}$ is emitted. Therefore, the choice of the heat generator affects the final performance of the system. A condensing boiler working at its highest efficiency (in case of floor heating) allows reducing primary energy consumption and $\mathrm{CO}_{2}$ emissions in operation phase by $11-15 \%$ depending on the system. 
Table 4. Primary energy consumption per square meter of the building during the life cycle phases in different heating systems

\begin{tabular}{llll}
\hline & $\begin{array}{l}\text { Radiators + simple boiler, } \\
\mathrm{MJ} / \mathrm{m}^{2}\end{array}$ & $\begin{array}{l}\text { Floor heating }+ \\
\text { condensing boiler, } \mathrm{MJ} / \mathrm{m}^{2}\end{array}$ & $\begin{array}{l}\text { Radiators }+ \text { condensing } \\
\text { boiler, } \mathrm{MJ} / \mathrm{m}^{2}\end{array}$ \\
\hline Materials production & 223 & 115 & 208 \\
Elements manufacture & 33 & 17 & 31 \\
Transportation & 12 & 6 & 12 \\
Reconstruction & 593 & 316 & 542 \\
Operation & 74956 & 63606 & 70500 \\
Total & 75817 & 64060 & 71293 \\
\hline
\end{tabular}

Table 5. $\mathrm{CO}_{2}$ emissions per square meter of the building during the life cycle stages of different heating systems

\begin{tabular}{llll}
\hline & $\begin{array}{l}\text { Radiators + simple boiler, } \\
\mathrm{kg} \mathrm{CO} / \mathrm{m}^{2}\end{array}$ & $\begin{array}{l}\text { Floor heating }+ \\
\text { condensing boiler, } \\
\mathrm{kg} \mathrm{CO}^{2} / \mathrm{m}^{2}\end{array}$ & $\begin{array}{l}\text { Radiators + condensing } \\
\text { boiler, } \mathrm{kg} \mathrm{CO} / \mathrm{m}^{2}\end{array}$ \\
\hline $\begin{array}{l}\text { Materials production } \\
\text { Elements manufacture }\end{array}$ & 15 & 7 & 15 \\
Transportation & 2 & 1 & 2 \\
Reconstruction & 40 & 0 & 1 \\
Operation & 4240 & 20 & 38 \\
Total & 4299 & 3607 & 3992 \\
\hline
\end{tabular}

\section{INTERPRETATION}

Since the purpose of this study is to compare the different heating systems during their life cycle phases, it has to be pointed out, which system and at which stage has the most significant effect on environment. The heating devices - steel radiators - have the biggest influence in the production phase. In this case the floor-heating system is much better and has more advantages, such as a higher comfort level. This system has one major disadvantage - investments are much higher. The analysis of operation stage of the systems show that compared with other stages of the life cycle the heat production in the boiler plays the most important role. This means that cast-iron boiler efficiency has to be improved. This can be done by replacing standard gas boiler with condensing gas boiler, the efficiency of which can reach $109 \%$.

\section{ANALYSIS APPLYING THE 3E CRITERIA}

The previously described the $3 \mathrm{E}$ method requires three values. To evaluate environmental impact of the three analysed systems, we have to calculate $\mathrm{CO}_{2}$ emissions during their life cycle and primary energy use for the whole life cycle. The last criteria - expenditures show the necessary investments for systems installation. It is calculated that the most expensive system (as it was expected) is the floor-heating system combined with the condensing boiler (54438 LTL or 15766 EUR). The cheapest system is that with radiators combined with a standard gas boiler (45284 LTL or 13115 EUR). The system including radiators combined with the condensing boiler costs 52768 LTL or 15283 EUR.

In this case there are no special preferences 


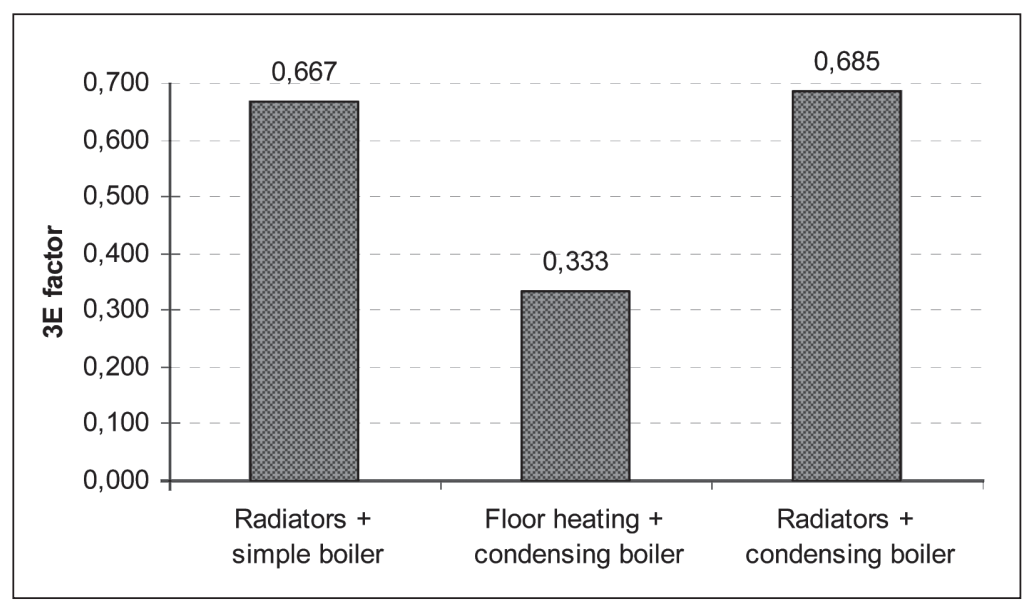

Figure 5. Comparison of heating systems based on $3 \mathrm{E}$ criteria

and all the criteria are regarded as having the same importance; therefore, all weight coefficients are set equal.

Results of the $3 \mathrm{E}$ are presented in Figure 5.

As it can be seen from the Figure 5, the best heating system is the floor-heating system combined with a condensing boiler. Though this system is the most expensive one, what makes it unattractive to the investor, its energy and environmental benefits allow prioritising the system.

Each $3 \mathrm{E}$ criteria value can be corrected depending on the priorities of the user, which can be expressed by setting different values of weight coefficients.

\section{DISCUSSION}

Final results of the study are compared here with similar studies, e.g. in Martinaitis (2001) several residential blocks of flats are analysed. According to this study, primary energy consumption of the heating system during the life cycle of the buildings amount to $48-87 \mathrm{GJ} / \mathrm{m}^{2}$. Results for different systems vary from 64-76 $\mathrm{GJ} / \mathrm{m}^{2}$ in the study.

Analysis shows that in all cases the operation stage is most important, and there the biggest energy consumption occurs. That means that it is not so important in this case what materials or elements are used in the system, much more important is the efficiency of the heat generator.

This study shows just three possible solutions using gas as fuel. Heating of residential building can be solved in different ways. Systems using renewable energy (such as wind, solar, geothermal) are the most effective from the environmental point of view, but these systems do not spread as fast we would like to because of their complexity, lack of know-how and wish to make bigger investments. This statement is not applied to the biomass, which is a widely used renewable energy source.

The overall conclusion is related to the sustainability issue. Today it becomes very important to coordinate the environmental and energy actions while considering economical issues at the same time. As it could be noticed, if only economical question is under consideration while designing a heating system, the priority will be given to the cheapest system. But then the effect on the environment and primary energy consumption will increase at the end. If we evaluate the damage and the increased consumption of the primary energy, the 
economical result would be completely different. So, while designing a heating system, it is relevant to use the life cycle and the $3 \mathrm{E}$ approaches. Especially when the reduction of greenhouse gas emissions obtained a real monetary value.

The approach used in this study could be applied for the evaluation of the whole building, its separate elements and engineering systems.

\section{REFERENCES}

Asif, M., Muneer, T. and Kelley, R. (2007) Life cycle assessment: A case study of a dwelling home in Scotland. Building and Environment, 42(3), p. 1391-1394.

Blanchard, S. and Reppe, P. (1998) Life cycle analysis of a residential home in Michigan. Report No 1998-5, Centre for sustainable systems, University Michigan, $60 \mathrm{p}$.

Bras, B. and Roman, F. (2006) An Introduction to Life Cycle Analysis/Assessment (LCA), Georgia Institute of Technology.

Department of Statistics under the Government of the Republic of Lithuania (2006) Energy balances 2001-2005, Vilnius: Department of Statistics under the Government of the Republic of Lithuania, $112 \mathrm{p}$.

Directive 2005/32/EC of the European Parliament and of the Council of 6 July 2005 establishing a framework for the setting of eco-design requirements for energy-using products and amending Council Directive 92/42/EEC and Directives 96/57/EC and 2000/55/EC of the European Parliament and of the Council (2005). Official Journal of the European Union, L 191, p. 29-58.

Directive 2006/32/EC of the European Parliament and of the Council of 5 April 2006 on energy end-use efficiency and energy services and repealing Council Directive 93/76/EEC (2006). Official Journal of the European Union, L 114, p. 64-85.

Dones, R., Gantner, U. and Hirschberg, S. (1999) Greenhouse gas total emissions from current and future electricity and heat supply systems. Proceedings of $4^{\text {th }}$ International Conference on Greenhouse Gas Control Technologies (GHGT-
4), Interlaken, Switzerland, 31 Aug.-2 Sept., Pergamon, Amsterdam, pp. 891-896.

Dones, R., Heck, T. and Hirschberg, S. (2003) Greenhouse Gas Emissions from Energy Systems: Comparison and Overview, PSI Annual Report 2003 Annex IV, Paul Scherrer Institute, Villigen, Switzerland.

European Commission (1997) European methodology for the evaluation of environmental impact of buildings, REGENER project final report, 2 Application of the life cycle analysis to buildings, $145 \mathrm{p}$.

Eurostat (2007) Eurostat yearbook 2006-07, Statistical Office of the European Communities; $<$ http://epp.eurostat.ec.europa.eu > [accessed $20070318]$.

Fava, J. A. (2006) Can ISO Life Cycle Assessment Standards Provide Credibility for LCA? International Conference on Life Cycle Assessment, Washington, D.C., May 8-10, p. 17-20.

International Aluminium Institute (2003) Life cycle assessment of aluminium: inventory data for the worldwide primary aluminium industry, $53 \mathrm{p}$.

International Aluminium Institute (2000) Life cycle inventory of the worldwide aluminium industry with regard to energy consumption and emissions of greenhouse gases, $8 \mathrm{p}$.

ISOPA (1998) APME Summary Report on Polyurethanes Precursors (TDI, MDI, Polyols), The European Isocyanate Producers; <http:// www.tud.ttu.ee/material/piirimae/eco-design/ matress/38.pdf> [accessed 2007-03-23].

Martinaitis, V. (2001) Thermodynamical analysis model of building life cycle. Monograph, Vilnius: Technika, 172 p. (In Lithuanian).

Moberg, A. (2006) Environmental systems analysis tools for decision-making. LCA and Swedish waste management as an example. Licentiate thesis, Stockholm: KTH, $56 \mathrm{p}$.

Ministry of Economy of the Republic of Lithuania (2004) National allocation plan for 2005-2007, Vilnius, 40 p. (In Lithuanian).

Nyman, M. and Simonson, C. J. (2005) Life cycle assessment of residential ventilation units in a cold climate. Building and Environment, 40(1), p. 15-27.

Pre Consultants bv (2006) SimaPro 7 Software, Data Base; <http://www.pre.nl/simapro/> [accessed 2006-08-26]. 
Prek, M. (2004) Environmental impact and life cycle assessment of heating and air conditioning systems, a simplified case study. Energy and Buildings, 36(10), p. 1021-1027.

European committee for standardisation (2003) prEN 13779:2003 Ventilation for non-residential buildings - performance requirements for ventilation and room-conditioning systems, Brussels.

Ministry of the Environment of the Republic of Lithuania (2001) Recommendations. Evaluation of life span of buildings and their elements, R27-01, Vilnius, 38 p. (In Lithuanian).

PSI (2004) Life Cycle Assessment', Paul Scherrer Institute; <http:/gabe.web.psi.ch/research/lca/> [accessed 2007-03-23].

Rogoža, A., Čiuprinskas, K. and Šiupšinskas, G. (2006) The optimisation of energy systems by using 3E factor: the case studies. Journal of Civil Engineering and Management, 12(1), p. 63-68.
Scheuer, C., Keoleian, G. A. and Reppe, P. (2003) Life cycle energy and environmental performance of a new university building: modelling challenges and design implications. Energy and Buildings, 35(10), p. 1049-1064.

Schmidt, D. (2004) Design of Low Exergy Buildings - Method and a Pre-Design Tool. International Journal of Low Energy and Sustainable Buildings, 3, p. 1-47.

Sustainable Agri-Food Production and Consumption Forum of the United Nations Environment Program (2000); <http://www.agrifood-forum.net/ practices/lca.asp > [accessed 2007-03-09].

Thormark, C. (2006) The effect of material choice on the total energy need and recycling potential of a building. Building and Environment, 41(8), p. 1019-1026.

U. S. Environmental protection agency (2006) Systems Analysis Research, Program Brief; <http:/ /www.epa.gov/ nrmrl/std/sab/lca/lca_brief.htm> [accessed 2007-03-23].

\section{SANTRAUKA}

\section{INDIVIDUALAUS GYVENAMOJO NAMO ŠILDYMO SISTEMOS GYVAVIMO CIKLO ANALIZE் Violeta SASNAUSKAITĖ, Lina UŽŠILAITYTĖ, Artur ROGOŽA}

Tiek Lietuvoje, tiek Europos Sajungoje pastatuose suvartojama apie $40 \%$ galutinès energijos. Šalto klimato šalyse pagrindinis energijos kiekis suvartojamas pastatams šildyti. Todèl statant energetiškai efektyvius pastatus labai svarbu dar projektuojant priimti teisingus sprendimus dẻl jų šildymo sistemų. Atliktos analizès tikslas buvo palyginti tris skirtingas šildymo sistemas darnaus vystymosi požiūriu. Straipsnyje pateikiami apibendrinti atliktos esamo gyvenamojo namo šildymo sistemų variantų gyvavimo ciklo analizès rezultatai: pirminès energijos sąnaudos, $\mathrm{CO}_{2}$ emisija ir investicijos per jų gyvavimo laiką. Sistemos įvertintos taikant daugiakriterinį vertinimą. Atliekant tyrimą buvo palyginti trys šildymo sistemų variantai: standartinis ketaus katilas su plieniniais radiatoriais, kondensacinis katilas su grindų šildymu ir kondensacinis katilas su plieniniais radiatoriais. Gyvavimo ciklo analizè atlikta imant, kad šildymo sistemos gyvavimo laikas yra 80 metų. Kaip galutinis vertinimo kriterijus pasiūlytas $3 \mathrm{E}$ kriterijus. 